\title{
Evaluation of the nutritional habits of second-year high school students in the Seferihisar region with the ecological framework
}

\author{
Avaliação dos hábitos nutricionais dos \\ alunos do segundo ano do ensino \\ médio na Região de Seferihisar \\ pelo modelo ecológico
}

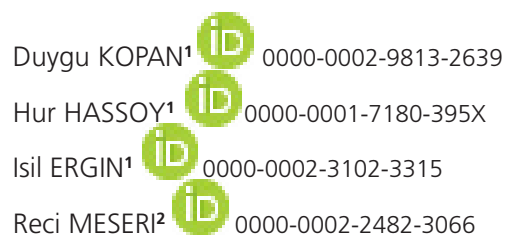

A B S T R A C T

\section{Objective}

The study aims to identify the nutritional habits of second-year high school students in Seferihisar, Turkey, and the factors associated thereof, based on the Ecological Framework.

\section{Methods}

In this cross-sectional study by a self-reported questionnaire, second-year high school students $(n=392)$ attending public schools in Seferihisar had their nutritional habits measured with the Adolescent Food Habits Checklist scale. The food habit score was calculated and associated factors were evaluated in 4 layers based on the Mary Story's Ecological Framework (individual factors, social, physical and macro-level environments). The data analysis for the association of these layers with the food habits score was executed through multi-level linear regression.

1 Ege University, Faculty of Medicine, Department of Public Health. Ege Üniversitesi Tip Fakültesi, 35100. Bornova-Izmir, Turkey. Correspondence to: H HASSOY. E-mail: <hur.hassoy@ege.edu.tr>.

2 Ege University, Faculty of Health Sciences, Department of Nutrition and Dietetics. Bornova-Izmir, Turkey.

Article elaborated from dissertation by D. KOPAN, entitled "Evaluation of nutrition habits of the second-grade students in Seferihisar Region with the Ecological Framework". Ege University; 2019.

How to cite this article

Kopan D, Hassoy H, Ergin I, Meseri R. Evaluation of the nutritional habits of second-year high school students in the Seferihisar region with the ecological framework. Rev Nutr. 2021;34:e200089. https://doi.org/10.1590/1678-9865202134e200089 


\section{Results}

Students' participation rate was $87.7 \%(n=344)$. Of all the layers (from individual factors to the influence of the social environment and macro-level environment: nutritional literacy, the food consumption of their peers at school, availability of fruits-vegetables at home, buying junk food at the school canteen, presence of posters at school, etc.), the option for advertised food items was statistically explanatory based on the linear regression analysis $(p<0.05)$.

\section{Conclusion}

The model derived from the Ecological Framework explained $45 \%$ of the nutritional habits with an equivalent contribution from the four layers. Availability of healthy food items where the students lived and higher levels of nutritional literacy led to healthy nutritional habits. Having healthy food items sold at school canteens at affordable prices, using posters to promote a healthy diet, and introducing nutrition-related courses into the curricula would support students in developing healthy nutritional habits.

Keywords: Adolescent. Feeding behavior. Nutritional assessment.

\section{RE S U M O}

\section{Objetivo}

O presente estudo almeja determinar os hábitos nutricionais de adolescentes do $2^{\circ}$ ano do Ensino Médio em Seferihisar, Turquia, e os fatores associados a esses hábitos no âmbito da Teoria Ecológica.

\section{Métodos}

Neste estudo transversal de questionário autoadministrado, os hábitos nutricionais de alunos do $2^{\circ}$ ano do Ensino Médio ( $n=392)$ de escolas públicas em Seferihisar foram avaliados através da escala da Lista de Verificação dos Hábitos Alimentares de Adolescentes. A pontuação de hábito alimentar foi calculada e os fatores associados foram avaliados em quatro camadas baseadas no modelo criado no âmbito da Teoria Ecológica de Mary Story (fatores individuais, sociais, físicos e ambientais de nível macro). A análise de dados para a associação dessas camadas com a pontuação dos hábitos alimentares foi executada através de regressão linear multinível.

\section{Resultados}

A taxa de participação dos alunos no estudo foi de $87,7 \%(n=344)$. Em relação a cada camada, foram avaliados desde fatores individuais, nível de conhecimento de nutrição, ambiente social, consumo de alimentos pelos colegas na escola, ambiente físico, disponibilidade de frutas e vegetais em casa, compras de comida sem qualidade na cantina da escola, presença de cartazes na escola e ambiente do nível macro. A preferência por alimentos anunciados foi estatisticamente explanatória com base na análise de regressão linear $(p<0,05)$.

\section{Conclusão}

O modelo derivado da Teoria Ecológica explicou 45\% dos hábitos nutricionais, com uma contribuição equivalente das quatro camadas. A presença de alimentos saudáveis no ambiente frequentado pelos alunos e um alto nível de conhecimento sobre nutrição trazem estimulam hábitos nutricionais saudáveis. A venda de alimentos saudáveis na cantina e no refeitório das escolas a presença de cartazes encorajando uma dieta saudável e a inclusão de cursos de nutrição no currículo tornarão mais conveniente aos alunos adotar um comportamento nutricional saudável.

Palavras-chave: Adolescente. Comportamento alimentar. Avaliação nutricional.

\section{INTRODUCTION}

Adolescence is a period of transition from childhood into adulthood, in which growth and development are accelerated, the person's degree of independence increases, and one starts developing behaviors. Nutrition is an important factor helping adolescents maintain overall good health, supporting their growth and development [1,2]. Nutritional behavior acquired during this period of life is carried into adulthood [3]. An adequate diet with sufficient, balanced consumption of energy and nutritional elements supports growth and development during adolescence [4]. Insufficient/excessive energy intake, insufficient fruit-vegetable intake, consumption of unhealthy food items such as fast food, lack of physical exercise, 
skipping meals, and adopting restricted diet programs during this period has effects on adolescents' long-term health and may trigger obesity, cancers, and mental disorders [1,3].

A study conducted by the World Health Organization (WHO) in 42 countries reported that $18.0 \%$ of all 15-year-old students were on diets to become thinner, $43.0 \%$ did not have breakfast, $67.0 \%$ did not consume any fruits daily, $19.0 \%$ consumed soft drinks on a daily basis, only $16.0 \%$ exercised for at least 60 minutes per day, and $63.0 \%$ watched television for 2 or more hours per day [5]. A study conducted in 29 cities in Turkey found that $64.4 \%$ of high school students skipped meals and that the most commonly skipped meal was breakfast (54.0\%) [6]. Studies carried out in Turkey among high school students revealed that $34.6 \%$ of students were on diets, $36.2 \%$ attempted to lose weight, $48.2 \%$ exercised moderately or intensely, $95.1 \%$ consumed at least one portion of fruits per day, $88.4 \%$ consumed mostly tea, $82.0 \%$ cola, $75.9 \%$ ready-made fruit juice, and $75.1 \%$ coffee [7-10].

The Ecological Framework is an integrated model based on the Ecological Systems and Social Cognitive Theory, that assesses factors associated with the nutritional habits of adolescents. Story et al. $[11,12]$ classified the factors associated with the nutritional habits of adolescents into individual factors, social, physical, and macro-level environments. Studies examining the nutritional habits of adolescents with this holistic approach are few and far between.

This study aims to identify the nutritional habits of tenth-grade students at public schools in the district of Seferihisar, in the province of Izmir, as well as the factors associated thereof via the model constructed on the basis of the Ecological Framework. In this context, our hypothesis is that the nutritional habits of adolescents are associated with individual factors, as well as with their social, physical, and macrolevel environments.

\section{METHODS}

The cross-sectional study was conducted in October-November 2018 in 6 public high schools in the Seferihisar district in the province of Izmir, Turkey. Seferihisar is a rural district in Turkey's Western Anatolia region, neighboring the Aegean Sea. The livelihood of the people in the region is mainly provided by agriculture and animal husbandry. The studied population consisted of all the second-year high school students in this district $(n=392)$. The objective was to cover the entire population. Inclusion criteria were: agreement to take part in the study, presence in school on the day of the data collection, and answering all the survey questions. The students completed the questionnaire through self-reporting. The Ethics Committee approval (decision n. 18-7.1/104) was obtained from the Research Ethics Committee of the Medical Faculty of Ege University.

The data were collected in the classrooms through a self-reported questionnaire responded by the students under the supervision of the researcher. The study's dependent variable was the students' nutritional habits. Nutritional habits were evaluated using the Adolescent Food Habits Checklist (AFHC) scale, developed by Johnson et al. [13]. The validity and reliability assessment of the scale in Turkish was conducted by Arikan et al. [14]. The AFHC scale consisted of 19 questions including answer choices "agree" and "disagree". Each correct answer for healthy eating was assigned 1 point. The total score was calculated by dividing the total number of questions by the numbers of questions that did not get 1 point. The highest score of the scale was 19; when 1 point is taken from all questions, the calculated score is also 19. An increased score indicated improvement in healthy nutritional habits.

Mary Story's Ecological Framework model was used to evaluate the independent variables influencing the adolescents' nutritional habits. This approach examined factors associated with dietary habits in 4 layers 
$[11,12]$. Adhering to the concepts of the Ecological Framework, the following variables were included in the study. In the first layer (Individual Factors), we examined: age, sex, living arrangements, wealth status, dieting status, mobile phone screen time, body weight perception, nutritional literacy level, and physical activity level. The wealth status was assessed with the Family Well-being Scale, which included 4 items: Car ownership, computer ownership, a room reserved for the child, the family vacations in the preceding year [15]. The nutritional literacy level was measured with a previously used scale with 8 questions. The mean $(6.37 \pm 1.41)$ was used as a cut off value to define the adequacy [16]. In the second layer (Social Environments), we included: if the father cares about the diet, if the mother provides guidance for the nutrition, if the mother is a role model in terms of nutrition, if the parents forbid food items, family meals, close friends on a diet, if he/she consumes the same food items as friends at school, if friends support the change in body weight. In the third layer (Physical Environments), we included: the regular availability of fruits-vegetables at home, buying junk food at school canteen, buying food \& beverage in the vicinities of the school, visuals promoting a healthy diet at school, and eating out with friends. In the fourth layer (Macro-Level Environments), we included: opting for advertised food items, adopting a celebrity's diet as a role model (Figure 1).

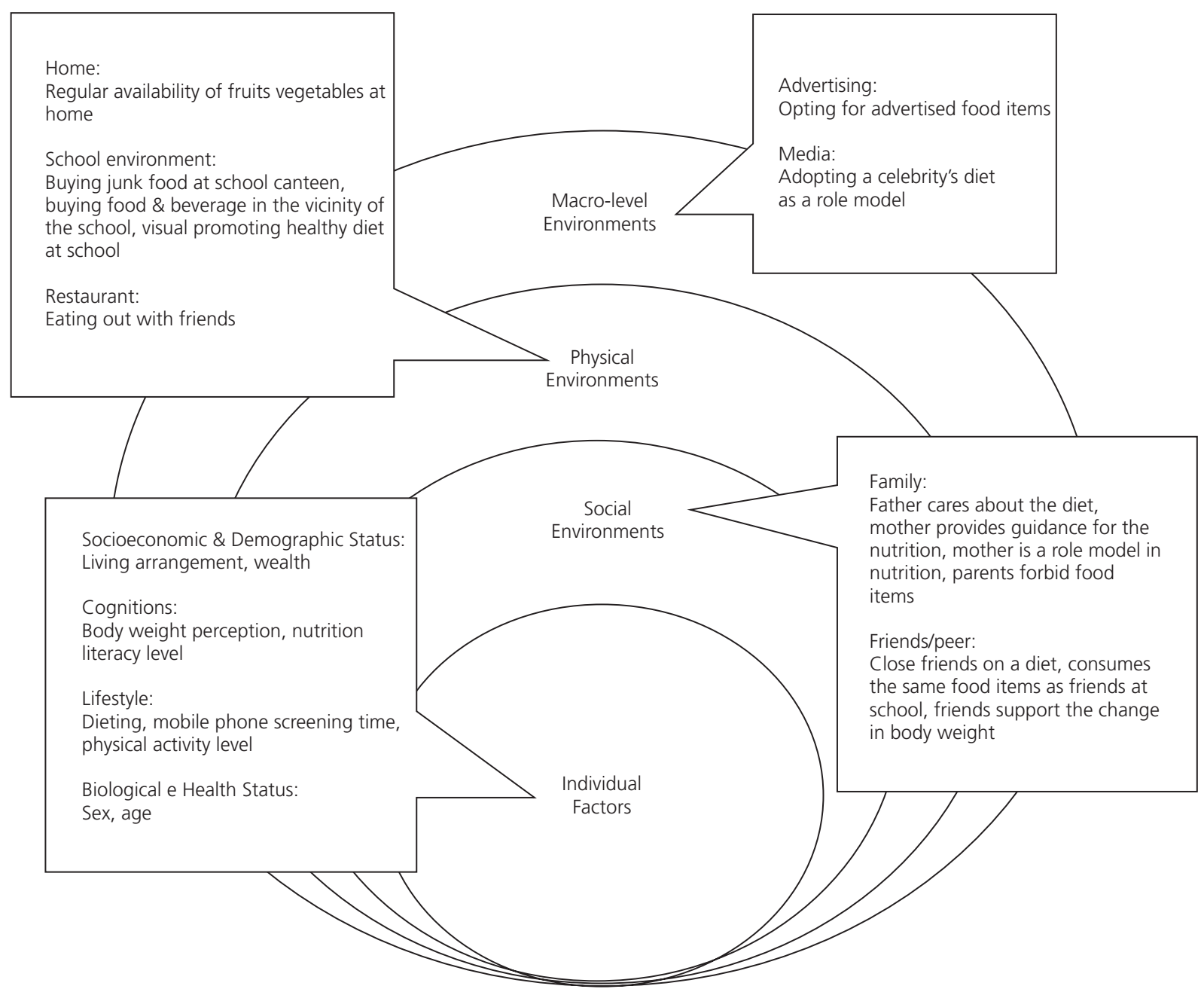

Figure 1 - Variables of the model, based on the Ecological Framework, included in the study. 
Data were evaluated using the SPSS 22.0 program. For paired comparisons, student's t-test and ANOVA were used while opting for multiple regression analysis in multivariate comparisons; $p<0.05$ was accepted as the limit of statistical significance. Factors that were revealed to be associated with nutritional habits in univariate analyses were then examined by multilevel analysis. We constructed models using associated factors and examined to what extent they were explanatory of nutritional habits.

\section{R E S U L T S}

Participated in the study (165 male and 179 female students $87.7 \%, \mathrm{n}=344$ ). The students' average age was $15.17 \pm 0.43(n=336)$. Female students' nutritional habits score was $10.83 \pm 3.87$, and male students' score was $10.34 \pm 4.03$. Individual factors and social environment variables associated with nutritional habits of students are shown in Table 1. The nutritional habits score of the students who lived with their parents, who were on a diet, who described their body as overweight, who had attained an adequate level of nutritional literacy, who used their mobile phones for less than 1 hour a day, whose parents forbade some food items, and who consumed the same food items as their friends at school was significantly higher $(p<0.05)$.

Table 1 - Individual and social environment factors associated with the nutritional habits of students.

1 of 2

\begin{tabular}{|c|c|c|c|c|}
\hline \multirow{2}{*}{ Individual Factors } & \multicolumn{2}{|c|}{ Distribution of students } & \multirow{2}{*}{$\begin{array}{c}\text { Nutritional habits } \\
\text { AFHC Score } \pm \text { SD }\end{array}$} & \multirow[t]{2}{*}{$p$} \\
\hline & $n$ & $\%$ & & \\
\hline$\overline{\text { Age }}$ & & & & 0.613 \\
\hline$\leq 15$ & 283 & 82.3 & $10.68 \pm 3.92$ & \\
\hline$>15$ & 53 & 15.4 & $10.38 \pm 4.23$ & \\
\hline Missing & 8 & 2.3 & & \\
\hline Sex & & & & 0.248 \\
\hline Female & 179 & 52.1 & $10.83 \pm 3.87$ & \\
\hline Male & 165 & 47.9 & $10.34 \pm 4.03$ & \\
\hline Living arrangements & & & & $0.032^{*}$ \\
\hline At home with parents & 333 & 96.8 & $10.68 \pm 3.92$ & \\
\hline Other & 11 & 3.2 & $8.09 \pm 4.25$ & \\
\hline Wealtha & & & & 0.107 \\
\hline Low & 168 & 48.8 & $10.26 \pm 3.75$ & \\
\hline Moderate & 139 & 40.4 & $10.69 \pm 4.14$ & \\
\hline High & 37 & 10.8 & $11.76 \pm 3.75$ & \\
\hline Dieting & & & & $0.006^{*}$ \\
\hline On a diet & 27 & 7.8 & $12.59 \pm 4.44$ & \\
\hline Not on a diet & 317 & 92.2 & $10.43 \pm 3.86$ & \\
\hline Mobile phone screen time (hour/day) ${ }^{\mathbf{a}}$ & & & & $0.001^{*}$ \\
\hline$<1$ & 20 & 5.8 & $12.55 \pm 4.07$ & \\
\hline $1-2$ & 78 & 22.7 & $11.65 \pm 3.69$ & \\
\hline$>2$ & 238 & 69.2 & $10.13 \pm 3.92$ & \\
\hline Missing & 8 & 2.3 & & \\
\hline Body weight perception & & & & $0.030^{*}$ \\
\hline Underweight & 61 & 17.7 & $9.51 \pm 3.36$ & \\
\hline Normal & 215 & 62.5 & $10.67 \pm 4.07$ & \\
\hline Overweight & 67 & 19.5 & $11.33 \pm 3.92$ & \\
\hline Missing & 1 & 0.3 & & \\
\hline
\end{tabular}


Table 1 - Individual and social environment factors associated with the nutritional habits of students.

2 of 2

\begin{tabular}{|c|c|c|c|c|}
\hline \multirow{2}{*}{ Individual Factors } & \multicolumn{2}{|c|}{ Distribution of students } & \multirow{2}{*}{$\frac{\text { Nutritional habits }}{\text { AFHC Score } \pm \text { SD }}$} & \multirow[t]{2}{*}{$p$} \\
\hline & $\mathrm{n}$ & $\%$ & & \\
\hline Nutritional literacy level & & & & $0.038^{*}$ \\
\hline Adequate & 253 & 73.5 & $10.92 \pm 4.04$ & \\
\hline Inadequate & 91 & 26.5 & $10.01 \pm 3.69$ & \\
\hline Physical Activity level ${ }^{\mathbf{a}}$ & & & & $0.008^{*}$ \\
\hline Insufficient & 124 & 36.0 & $9.79 \pm 3.70$ & \\
\hline Light physical activity & 75 & 21.9 & $11.39 \pm 4.02$ & \\
\hline Vigorous physical activity & 93 & 27.0 & $11.05 \pm 4.02$ & \\
\hline Missing & 52 & 15.1 & & \\
\hline \multicolumn{5}{|l|}{ Social Environments } \\
\hline Father cares about the diet & & & & $0.002^{*}$ \\
\hline Yes & 186 & 54.1 & $11.16 \pm 3.85$ & \\
\hline No & 141 & 41.0 & $9.79 \pm 3.90$ & \\
\hline Missing & 17 & 4.9 & & \\
\hline Mother provides guidance for the nutrition & & & & $<0.001^{* *}$ \\
\hline Yes & 292 & 84.8 & $10.94 \pm 3.87$ & \\
\hline No & 51 & 14.8 & $8.61 \pm 3.88$ & \\
\hline Missing & 1 & 0.4 & & \\
\hline Mother is a role model in nutrition & & & & $<0.001^{* *}$ \\
\hline Yes & 129 & 37.5 & $11.58 \pm 4.10$ & \\
\hline No & 212 & 61.6 & $9.99 \pm 3.73$ & \\
\hline Missing & 3 & 0.9 & & \\
\hline Parents forbid food items & & & & $0.001^{*}$ \\
\hline Yes & 164 & 47.6 & $11.34 \pm 3.90$ & \\
\hline No & 179 & 52.0 & $9.92 \pm 3.89$ & \\
\hline Missing & 1 & 0.3 & & \\
\hline Family meals (at least once a day) & & & & 0.059 \\
\hline Yes & 318 & 92.4 & $10.71 \pm 3.96$ & \\
\hline No & 26 & 7.6 & $9.19 \pm 3.58$ & \\
\hline Close friends on a diet & & & & $0.031^{*}$ \\
\hline Yes & 171 & 49.7 & $11.04 \pm 4.06$ & \\
\hline No & 168 & 48.8 & $10.11 \pm 3.82$ & \\
\hline Missing & 5 & 1.5 & & \\
\hline Consumes the same food items as friends at school & & & & $<0.001^{* *}$ \\
\hline Yes & 202 & 58.7 & $9.87 \pm 3.86$ & \\
\hline No & 138 & 40.1 & $11.78 \pm 3.79$ & \\
\hline Missing & 4 & 1.2 & & \\
\hline Friends support the change in body weight & & & & $0.016^{*}$ \\
\hline Yes & 227 & 67.9 & $10.95 \pm 3.85$ & \\
\hline No & 107 & 32.1 & $9.84 \pm 3.96$ & \\
\hline
\end{tabular}

Note: ${ }^{a}$ ANOVA test was used ${ }^{*} p<0.05,{ }^{* *} p<0.001$. AFHC: Adolescent Food Habits Checklist; SD: Standard Deviation.

The Table 2 shows the physical and macro-level environmental variables associated with the nutritional habits of students. Those students who had fruits and vegetables available at home on a regular basis, who bought junk food at the canteen, who bought food items and beverages at sales points in the vicinities of the school, who had banners, posters promoting a healthy diet at school, who received training on nutrition at school at least once, who did not eat out, and who did not opt for advertised food items obtained significantly higher scores on nutritional habits $(p<0.05)$. 
Table 2 - Physical and macro-level environment factors associated with the nutritional habits of students.

\begin{tabular}{|c|c|c|c|c|}
\hline \multirow{2}{*}{ Physical Environment Factors } & \multicolumn{2}{|c|}{ Distribution of students } & \multirow{2}{*}{$\begin{array}{l}\text { Nutritional habits } \\
\text { AFHC Score } \pm S D\end{array}$} & \multirow{2}{*}{$p$} \\
\hline & $\mathrm{n}$ & $\%$ & & \\
\hline Regular availability of fruits-vegetables at home & & & & $0.002^{*}$ \\
\hline Yes & 319 & 92.7 & $10.78 \pm 3.89$ & \\
\hline No & 25 & 7.3 & $8.28 \pm 3.95$ & \\
\hline Buying junk food at the school canteen & & & & $0.004^{*}$ \\
\hline Yes & 165 & 47.9 & $9.96 \pm 3.70$ & \\
\hline No & 179 & 52.1 & $11.18 \pm 4.08$ & \\
\hline Buying food $\&$ beverage in the vicinities of the school & & & & $0.009^{*}$ \\
\hline Yes & 206 & 59.8 & $10.14 \pm 3.98$ & \\
\hline No & 138 & 40.2 & $11.28 \pm 3.80$ & \\
\hline Visuals promoting a healthy diet at school & & & & $0.008^{*}$ \\
\hline Yes & 40 & 11.6 & $12.15 \pm 3.49$ & \\
\hline No & 302 & 87.8 & $10.39 \pm 3.98$ & \\
\hline Missing & 2 & 0.6 & & \\
\hline Eating out with friends & & & & $0.013^{*}$ \\
\hline Yes & 236 & 68.6 & $10.24 \pm 3.99$ & \\
\hline No & 108 & 31.4 & $11.38 \pm 3.74$ & \\
\hline \multicolumn{5}{|l|}{ Macro-Level Environment Factors } \\
\hline Opting for advertised food items & & & & $<0.001^{* *}$ \\
\hline Yes & 194 & 56.4 & $9.60 \pm 3.60$ & \\
\hline No & 145 & 42.1 & & \\
\hline Missing & 5 & 1.5 & & \\
\hline Adopting a celebrity's diet as a role model & & & & $<0.001^{* *}$ \\
\hline Yes & 122 & 35.4 & $11.63 \pm 3.95$ & \\
\hline No & 222 & 64.6 & $10.03 \pm 3.83$ & \\
\hline
\end{tabular}

Note: ${ }^{*} p<0.05 ;{ }^{* *} p<0.001$. AFHC: Adolescent Food Habits Checklist; SD: Standard Deviation.

The Table 3 shows the results of the multiple linear regression analysis of the variables identified to be associated with nutritional habits. According to the regression analysis, out of all individual factors, dieting, mobile phone screen time (hour/day), nutritional literacy level, and physical activity level were explanatory of nutritional habits. Model 1 was $14.0 \%$ explanatory of nutritional habits. Among the social environments, nutritional guidance by the mother and consuming the same food items as friends at school were explanatory of nutritional habits. Mobile phone screen time, nutritional literacy level, and physical activity level were still explanatory of nutritional habits under Model 2. Model 2 was 28.7\% explanatory of nutritional habits. Among the physical environments, buying junk food at the school canteen and the presence of banners or posters promoting healthy nutrition at the school were explanatory of nutritional habits. Under Model 3, the nutritional literacy level and consuming the same food items as friends at school continued to be explanatory, following the addition of physical environments to the model. Model 3 was $37.5 \%$ explanatory of nutritional habits.

Among the macro-level environments, opting for advertised food items ( $\beta: 0.28,95 \% \mathrm{Cl}$ :0.09-0.45) was explanatory of nutritional habits. Under Model 4, nutritional literacy level ( $\beta: 0.23,95 \% \mathrm{Cl}: 0.06-0.40)$, consuming the same food items as friends at school $(\beta: 0.26,95 \% \mathrm{Cl}: 0.08-0.42)$, regular availability of fruit-vegetables at home ( $\beta: 0.20,95 \% \mathrm{Cl}: 0.03-0.37)$, buying junk food at the school canteen $(\beta: 0.18,95 \% \mathrm{Cl}: 0.01-0.35)$, and the presence of banners or posters promoting healthy nutrition at school $(\beta: 0.17,95 \% \mathrm{Cl}: 0.01-0.33)$ remained statistically explanatory for nutritional habits. Model 4 was $44.8 \%$ explanatory of nutritional habits. 
Table 3 - Multiple Linear Regression Analysis of the Determinants of Nutritional Habits.

\begin{tabular}{|c|c|c|c|c|c|c|c|c|}
\hline \multirow{2}{*}{ Individual Factors } & \multicolumn{2}{|c|}{ Model 1} & \multicolumn{2}{|c|}{ Model 2} & \multicolumn{2}{|r|}{ Model 3} & \multicolumn{2}{|c|}{ Model 4} \\
\hline & $\beta$ & $95 \% \mathrm{Cl}$ & $\beta$ & $95 \% \mathrm{Cl}$ & $\beta$ & $95 \% \mathrm{Cl}$ & $\beta$ & $95 \% \mathrm{Cl}$ \\
\hline $\begin{array}{l}\text { Living Arrangements (at home with parents/ } \\
\text { other) }\end{array}$ & 0.11 & $-0.01-0.21$ & 0.10 & $-0.01-0.21$ & 0.01 & $-0.13-0.16$ & 0.03 & $-0.14-0.19$ \\
\hline Dieting (yes/no) & 0.15 & $0.03-0.25^{*}$ & 0.09 & $-0.01-0.20$ & 0.08 & $-0.08-0.25$ & 0.09 & $-0.07-0.25$ \\
\hline Mobile phone screen time ( $\leq 2$ hours/ $>2$ hours) & 0.19 & $0.07-0.29^{*}$ & 0.16 & $0.05-0.27^{*}$ & 0.18 & $-0.01-0.35$ & 0.11 & $-0.06-0.28$ \\
\hline Nutritional literacy (adequate/inadequate) & 0.20 & $0.08-0.30^{*}$ & 0.16 & $0.04-0.26^{*}$ & 0.24 & $0.27-0.41^{*}$ & 0.23 & $0.06-0.40^{*}$ \\
\hline Level of physical activity (sufficient/insufficient) & 0.14 & $0.02-0.25^{*}$ & 0.12 & $0.01-0.22^{*}$ & 0.04 & $-0.14-0.22$ & 0.03 & $-0.20-0.15$ \\
\hline \multicolumn{9}{|l|}{ Social Environment Factors } \\
\hline Father cares about his diet (yes/no) & & & 0,07 & $-0.04-0.18$ & 0.11 & $-0.06-0.29$ & 0.09 & $-0.08-0.27$ \\
\hline Mother provides guidance about diet (yes/no) & & & 0,13 & $0.01-0.24^{*}$ & 0.01 & $-0.18-0.19$ & 0.01 & $-0.16-0.19$ \\
\hline Mother is a role model in diet (yes/no) & & & 0,10 & $-0.01-0.20$ & 0.10 & $-0.07-0.28$ & 0.11 & $-0.06-0.28$ \\
\hline Close friends on a diet (yes/no) & & & 0.08 & $-0.02-0.19$ & 0.03 & $-0.14-0.20$ & 0.08 & $-0.08-0.24$ \\
\hline $\begin{array}{l}\text { Consuming the same food that friends do at } \\
\text { school (no/yes) }\end{array}$ & & & 0.26 & $0.15-0.36^{* *}$ & 0.28 & $0.11-0.45^{*}$ & 0.26 & $0.08-0.42^{*}$ \\
\hline $\begin{array}{l}\text { Friends' support to body weight change (support/ } \\
\text { do not support) }\end{array}$ & & & 0.09 & $-0.02-0.20$ & 0.05 & $-0.12-0.21$ & 0.07 & $-0.09-0.23$ \\
\hline \multicolumn{9}{|l|}{ Physical Environment Factors } \\
\hline $\begin{array}{l}\text { Regular availability of fruits-vegetables at home } \\
\text { (yes/no) }\end{array}$ & & & & & 0.16 & $-0.01-0.33$ & 0.2 & $0.03-0.37^{*}$ \\
\hline Buying junk food at school canteen (no/yes) & & & & & 0.20 & $0.02-0.37^{*}$ & 0.18 & $0.01-0.35^{*}$ \\
\hline $\begin{array}{l}\text { Presence of banners, posters promoting a healthy } \\
\text { diet at school (yes/no) }\end{array}$ & & & & & 0.20 & $0.02-0.37^{*}$ & 0.17 & $0.01-0.33^{*}$ \\
\hline Eating out with friends (no/yes) & & & & & 0.08 & $-0.09-0.25$ & 0.08 & $-0.09-0.24$ \\
\hline \multicolumn{9}{|l|}{ Macro-level Environment Factors } \\
\hline Opting for advertised food items (no/yes) & & & & & & & 0.28 & $0.09-0.45^{*}$ \\
\hline $\begin{array}{l}\text { Adopting the diet of a person in the media as a } \\
\text { role model (yes/no) }\end{array}$ & & & & & & & 0.14 & $-0.03-0.30$ \\
\hline \multicolumn{9}{|l|}{ Explanatory and significance levels of the models } \\
\hline$R^{2}:$ & & 0.14 & & 0.287 & & 0.375 & & 0.448 \\
\hline Adj. $R^{2}$ : & & 0.125 & & 0.255 & & 0.274 & & 0.343 \\
\hline$p$ & & $<0.001$ & & $<0.001$ & & $<0.001$ & & $<0.001$ \\
\hline
\end{tabular}

Note: $R^{2}$ : Coefficient of determination; ${ }^{*} p<0.05 ;{ }^{* *} p<0.001$. Cl: Confidence Interval.

\section{DISCUSSION}

The study showed that the nutritional habits of adolescents were associated with individual factors, social, physical, and macro-level environments regarding the four layers of the Ecological Framework. The model was $44.8 \%$ explanatory for drivers of nutritional habits of this age group. The average AFHC score detected among the students was parallel to the findings in national and international studies conducted with similar age groups [13,17-20]. In the first layer of the model (Individual Factors), this score was in association with the students' nutritional literacy levels, implying higher scores at better literacy levels. Asakura et al. [21] found an association between children's high nutritional literacy levels and families with high level of vegetable consumption.

A study conducted with 241 high school students in the Gümüşhane province of Turkey found that the majority of the students with inadequate nutritional literacy ate fast-food on a daily basis [22]. Similarly, it was noted that when students' self-sufficiency and nutritional literacy improved, they consumed less unhealthy snacks [23].

In the second layer (social environment), not consuming the same food as friends at school was associated with adolescents' healthy eating. Adolescents sharing the same environment (school, 
neighborhood, classes etc.) tended to observe and adopt each other's diets. The dietary behaviors of friends were also associated with the nutritional habits of adolescents. Studies found correlations between adolescents who have friends with unhealthy diets and them opting for such food items [24-26]. It was noted that those students who were encouraged by their peers to have unhealthy diets did have them [8].

In the third layer (physical environments), we found that three components contributed to the adolescents' healthy eating habits: the regular availability of fruits-vegetables at home, buying junk food at the school canteen, the presence of banners or posters promoting a healthy diet at school. Having unhealthy food items and soft drinks readily available at home increased their consumption [12]. A study conducted by Vepsäläinen et al. [27] in 12 countries revealed a link between the nutritional environment at home and healthy and unhealthy eating patterns. The study conducted by Verstraeten et al. [28] associated access to healthy food items at schools (excepting soft drinks consumption) with healthy nutritional habits of adolescents. According to a study conducted in Turkey, fruit and vegetable consumption was associated with accessibility to the fruits and vegetables at home and at school [8]. The continuity in the healthy context (availability, access, and promotion of healthy food) at home and at school strengthens the possibilities of the adolescent making healthy choices.

At the fourth level (macro-level environment), opting for advertised food items was related with the students' healthy eating habits. There are studies showing that children and adolescents are influenced by food commercials $[29,30]$. Food industries advertise more for fast food, high-calorie foods, fizzy drinks, and sugary corn flakes [31].

A study from Turkey showed that the students immediately buy and consume foods and beverages which appear on television advertisements [32]. According to a study with 1,011 students in Brazil, food advertisements were associated with a greater level of consumption of fried foods, sweets, and snacks [30]. The model indicated that such advertisements accounted for almost half of the drivers of the nutritional habits of the adolescents. This is fairly a good proportion to understand the influencers on adolescents' healthy eating habits. Each layer contributed equally to the model, pointing out the necessity of a multifaceted and multi-layered approach to understand healthy nutrition. The first three layers had enough parameters to evaluate, and among those, a selection of variables reached the last model.

However, the macro level layer (fourth layer) of the framework could only be partially reflected to the model, regarding the scarce options to question at individual level. Macro level variables such as nutritional and agricultural policies could not be fully evaluated. This limits our understanding to an interpretation of the macro environment by the individual, rather than an objective evaluation. Moreover, this layer lacked the abundance of variables that other layers had, which results in an incomplete contribution of this layer. Thus, improving the tools that focus and define macro environment reflections at the individual level may contribute to the model and increase the degree of explanation.

Since ours is a cross-sectional study, we examined the causalities simultaneously. It could not be identified whether adolescents' unhealthy diets were fueled by the unhealthy food items available in their physical environment or if adolescents with unhealthy diets tended to consume unhealthy food items. The results of the study can only be generalized to the researched population. Data were collected based on students' self-reporting, which raises the possibility of response bias.

\section{CONCLUSION}

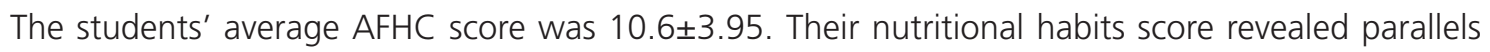
with the results of international studies. Students' nutritional habits were associated with four layers of the 
model constructed based on the Ecological Framework. Nutritional literacy level, consuming the same food items as their friends at school, buying junk food at the school canteen, presence of banners or posters promoting a healthy diet at school, and opting for advertised food items were the factors most highly associated with students' nutritional habits. Selling healthy food items at school canteens and cafeterias at affordable prices, having banners or posters promoting a healthy diet, introducing nutrition-related courses into the curricula would further support students in developing healthy eating habits.

\section{CONTRIBUTORS}

D. KOPAN was responsible for data collection, analysis, interpretation, discussion, and writing of the manuscript. H. HASSOY, designed the original study, coordinated the data collection and manuscript development, and contributed to data analysis and discussion. I. ERGIN and R. MESERI were responsible for coordinating the investigation, guiding the analyses, and revising the final version of the manuscript. All authors declare that there is no conflict of interest regarding this study.

\section{REFERENCES}

1. Lawless M, Shriver LH, Wideman L, Dollar JM, Calkins SD, Keane SP, et al. Associations between eating behaviors, diet quality and body mass index among adolescents. Eating Behaviors. 2020 [cited: 2021 May 15];36. Available from: https://www.sciencedirect.com/science/article/abs/pii/S1471015318304227

2. Altay M, Cabar HD, Altay B. Nutrition and school health in adolescence. Sinop Üniversitesi Sosyal Bilimler Dergisi. 2018 [cited: 2021 May 15];30;2(1):173-80. Available from: http://dergipark.org.tr/en/download/article-file/497124

3. Pearson N, Griffiths P, Biddle SJH, Johnston JP, Haycraft E. Individual, behavioural and home environmental factors associated with eating behaviours in young adolescents. Appetite. 2017 [cited: 2021 May 15];112:35-43. Available from: https://linkinghub.elsevier.com/retrieve/pii/S0195666317300041

4. Mason TB, Do B, Wang S, Dunton GF. Ecological momentary assessment of eating and dietary intake behaviors in children and adolescents: a systematic review of the literature. Appetite. 2020 [cited: 2021 May 15];144:104465. Available from: https://pubmed.ncbi.nlm.nih.gov/31541670/

5. Inchley J, Currie D, Young T, Samdal O, Torsheim T, Augustson L, et al. Growing up unequal: health behaviour in school-aged children (HBSC) study: International Report From the 2013/2014 Survey. WHO Regional Office for Europe. 2016 [cited: 2021 May 15]. Available from: https://www.euro.who.int/_data/assets/pdf_file/0003/303438/ HSBC-No.7-Growing-up-unequal-Full-Report.pdf

6. Kristo AS, Gültekin B, Öztağ M, Sikalidis AK. The effect of eating habits' quality on scholastic performance in Turkish adolescents. Behav Sci. 2020;10(1):31. https://doi.org/10.3390/bs10010031

7. Bayan M, Yaman M. Relation between parents educational status and food habits \& beliefs of adolescants. J Int Social Res. 2019;12(67):1082-93. https://doi.org/10.17719/jisr.2019.3796

8. Aygün Ö, Karayağız Muslu G. Vegetable and fruit consumption behaviours of secondary and high school students. Turkish J Family Med Prim Care. 2017;11(4):245-55. https://doi.org/10.21763/tjfmpc.359809

9. Sarıdağ Devran B, Saka M. The effect of nutrition education on nutritional habits, nutritional knowledge and physical activity of high school students. TDD J Nut Diet. 2019;47(3):5-14.

10. Gürel AN, Hisar F. The relationship between sugar- sweetened beverage consumption and obesity in adolescents. J Hacettepe Uni Fac Nurs. 2018;5(3):177-91.

11. Story M, Neumark-Sztainer Di, French S. Individual and environmental influences on adolescent eating behaviors. J Ame Diet Assoc. 2002;102(3):S40-51. https://doi.org/10.1016/S0002-8223(02)90421-9

12. Story M, Kaphingst KM, Robinson-O'Brien R, Glanz K. Creating healthy food and eating environments. Annu Rev Public Health. 2008;29(1):253-72. https://doi.org/10.1146/annurev.publhealth.29.020907.090926

13. Johnson F, Wardle J, Griffith J. The adolescent food habits checklist: reliability and validity of a measure of healthy eating behaviour in adolescents. Eur J Clin Nutr. 2002;56(7):644-9. https://doi.org/10.1038/sj.ejcn.1601371 
14. Arıkan I, Aksu AE, Metintaş S, Kalyoncu C. The adaptation of the adolescent food habit checklist to the Turkish adolescents. Prev Med Bull. 2012;11(1):49-51.

15. Currie CE, Elton RA, Todd J, Platt S. Indicators of socioeconomic status for adolescents: the WHO health behaviour in school-aged children survey. Health Educ Res. 1997;12(3):385-97. https://doi.org/10.1093/her/12.3.385

16. Şanlıer N, Konaklığlu E, Güçer E. Relationship between nutrition knowledge, habits and behaviors of young people and body mass index. Gazi Uni J Faculty Edu. 2009;29(2):333-52.

17. Limbers CA, Egan K, Cohen A. Executive functions and dietary behaviors in school-aged children. Int J Sch Health. 2018 [cited: 2021 May 15];5(1). Available from: https://www.researchgate.net/publication/322092807_Executive_ Functions_and_Dietary_Behaviors_in_School-Aged_Children

18. Kalkan I, Sonay Türkmen A, Filiz E. Dietary habits of Turkish adolescents in Konya, Turkey. Glob J Adv Pure Appl Sci. 2016 [cited: 2021 May 15];7(7):190-6. Available from: https://www.researchgate.net/publication/323040948_ Dietary_habits_of_Turkish_adolescents_in_Konya_Turkey

19. Kalkan I. The impact of nutrition literacy on the food habits among young adults in Turkey. Nutr Res Practice. 2019 [cited: 2021 May 15];13(4):352-7. Available from: https://www.ncbi.nlm.nih.gov/pubmed/31388412

20. Koca B, Arkan G. The relationship between adolescents' nutrition literacy and food habits and affecting factors. Public Health Nutr. 2020;(3):1-12.

21. Asakura K, Todoriki H, Sasaki S. Relationship between nutrition knowledge and dietary intake among primary school children in Japan: combined effect of children's and their guardians knowledge. J Epidemiol. 2017;27(10):483-91. https://doi.org/10.1016/j.je.2016.09.014

22. Tayhan Kartal F, Arslan Burnaz N, Yaşar B, Sağlam S, Kıymaz M. Investigation of the effect of nutrition knowledge levels of adolescents on their nutritional and exercising habits. Celal Bayar Üniversitesi Beden Eğitimi ve Spor Bilimleri Dergisi. 2019 [cited: 2021 May 15];14(2):280-95. Available from: https://www.researchgate.net/publication/338279804_ Adolesanlarin_Beslenme_Bilgi_Duzeylerinin_Beslenme_ve_Egzersiz_Aliskanliklari_Uzerine_Etkisinin_Incelenmesi

23. Yazdi Feyzabadi V, Karimi-Shahanjarini A, Rashidian A, Keshavarz Mohammadi N, Nedjat S, Omidvar N. Factors associated with unhealthy snacks consumption among adolescents in Iran's schools. Int J Health Policy Manag. 2017;6(9):519-28. https://doi.org/10.15171/ijhpm.2017.09

24. Banna JC, Buchthal OV, Delormier T, Creed-Kanashiro HM, Penny ME. Influences on eating: a qualitative study of adolescents in a periurban area in Lima, Peru. Bmc Public Health. 2016;16(1):1-11. https://doi.org/10.1186/s12889016-2724-7

25. Pace U, D'Urso G, Zappulla C. Negative eating attitudes and behaviors among adolescents: the role of parental control and perceived peer support. Appetite. 2018;121:77-82. https://doi.org/10.1016/j.appet.2017.11.001

26. Ragelienè T, Grønhøj A. The influence of peers' and siblings' on children's and adolescents' healthy eating behavior: a systematic literature review. Appetite. 2020;148.

27. Vepsäläinen H, Mikkilä V, Erkkola M, Broyles ST, Chaput J, Hu G, et al. Association between home and school food environments and dietary patterns among 9-11-year-old children in 12 countries. Int J Obesity Suppl. 2015 [cited: 2021 May 15];5(S2):66-73. Available from: http://www.nature.com/articles/ijosup201522

28. Verstraeten R, Leroy JL, Pieniak Z, Ochoa-Avilès A, Holdsworth M, Verbeke W, et al. Individual and environmental factors influencing adolescents' dietary behavior in low- and middle-income settings. Zeeb $\mathrm{H}$, editor. Plos One. 2016;11(7):e0157744. https://doi.org/10.1371/journal.pone.0157744

29. Qutteina Y, De Backer C, Smits T. Media food marketing and eating outcomes among pre-adolescents and adolescents: a systematic review and meta-analysis. Obesity Rev. 2019 [cited: 2021 May 15];20(12):1708-19. Available from: https://www.ncbi.nlm.nih.gov/pubmed/31468652

30. Delfino LD, Tebar WR, Silva DAS, Gil FCS, Mota J, Christofaro DGD. Food advertisements on television and eating habits in adolescents: a school-based study. Rev Saúde Pública. 2020;54:1-8.

31. Oliveira JS, Barufaldi LA, Abreu GA, Leal VS, Brunken GS, Vasconcelos SML, et al. ERICA: use of screens and consumption of meals and snacks by Brazilian adolescents. Rev Saúde Pública. 2016;50(Suppl1). https://doi. org/10.1590/s01518-8787.2016050006680

32. Özpulat F. The relationship between sugar- sweetened beverage consumption and obesity in adolescents. J Hum Sci. 2017;14(4):4123-34. 